\title{
Digital Educational Game Usage Scale: Adapting to Turkish, Validity and Reliability Study
}

\author{
Okan Sarıgöz ${ }^{1, *}$, Yavuz Bolat ${ }^{1} \&$ Selçuk Alkan ${ }^{1}$ \\ ${ }^{1}$ Department of Curriculum and Instruction, Faculty of Education, Hatay Mustafa Kemal University, Hatay, Turkey \\ *Correspondence: Department of Curriculum and Instruction, Faculty of Education, Hatay Mustafa Kemal University, \\ Hatay, Turkey. E-mail: okan.sarigoz@gmail.com
}

Received: July 5, 2018

Accepted: August 23, $2018 \quad$ Online Published: October 17, 2018

doi:10.5430/wje.v8n5p130

URL: https://doi.org/10.5430/wje.v8n5p130

\begin{abstract}
The purpose of this study is to adapt Digital Educational Games Usage Scale (DEGUS) that was developed by Bonanno \& Kommers (2008) to Turkish with the companion of a group of university students studying in department of English Teaching. In order for scale items to be the same in terms of language, firstly the translations of the items were carried out both from English to Turkish and Turkish to English, afterwards examining the forms gathered from the students, significant and positive correlations were detected among the data. Exploratory and confirmatory factor analyses revealed that the scale had four dimensions. In item total correlation calculation of the scale it was observed that all the items were above .40, item factor loads varied between .51 and .68, Cronbach Alpha internal consistency coefficient was .78 and test retest correlation was .88. Significant relations were in the calculations regarding the correlation analyses of the scale.
\end{abstract}

Keywords: digital educational games, scale, adaptation, reliability, validity

\section{Introduction}

We are living in an era where scientific and technological developments take place. Especially in technological stage, every year recent improvements occur newly produced tools, equipment and materials are placed on the market commercially. These rapid changes in technology have influenced the educational systems by time and new tools and materials have begun to appear in educational environments (Rock \& Brumbaugh, 2010). Softwares, especially the development in digital games related to software raised the idea of using digital games in education.

One way of relieving the classroom atmosphere in education is to take advantage of stories and games (Dönger, Özkartal \& Sarıgöz, 2017). When the games are used for the purpose of the lesson, they are very suitable tools especially for the children of primary school age to love lessons (Gelen \& Özer, 2010: 72). Similarly, when designed in a way to meet the needs of students, digital games contribute to the education (Prensky, 2003). In literature it was seen that many digital games that were designed for students were beneficial in education, especially on mathematics (Feng, 2008; Kim \& Chang, 2010; Chen et. al., 2012). Not only in the education of mathematics but also in language (Jong, Hong \& Yen, 2013), science (Clark, Nelson, Sengupta \& D’Angelo, 2009), engineering and positive sciences (Mayo, 2007), health and medical sciences (Boulos, Hetherington \& Wheeler, 2007), physical education (Papastergiou, 2009) and many more fields, digital games contribute to the teaching and learning.

Digital games have many other benefits to students besides learning (Sarıöz, 2016). Mainly, by digital games, students actively participate in class (Chen et. al, 2015). Also, digital games can be used effectively in problem solving activities and can provide the necessary environment for students to improve their problem-solving skills, thus developing conceptual learning (Admiraal, Huizenga, Akkerman \& Dam, 2011). Utilizing the main characteristics of digital games, students can create models and representations to be used in problem solving activities (Van Garderen, 2007). In addition, with digital games students can develop their reasoning skills and make up different cases without having to be confined to a single setting (Virk, Clark \& Singapurk, 2015). Also, digital games present to students the opportunity to go back to steps of problem solving or start all over again (Bartek \& Nocar, 2016).

It was also seen that digital games develop the critical thinking skills of students (Yang \& Chang, 2013). While 
playing digital games, it was found that students were required to use their critical thinking skills (Ennis, 1989). Digital games not only help student develop cognitively but also help them develop affectively and kinesthetically (Sarıöz, 2012)

Moreover, digital games help students have fun while learning. They help student learn and have increased attention to class, greater academic success and motivation ( $\mathrm{Li}$ et. al., 2016). Digital games are more enjoyable than traditional classes as well as the classes with activities involving the use of materials such as paper, scissors, glue etc. (Castellar, All \& Looy, 2015). Especially the sound and visual effects of digital games and the fact that ranking during the game presents the instant feedback attract the attention of students and influence their motivations along with their manners (Foster \&Shah, 2016). The fact that digital games teach while making you have fun and depend on abilities contributes to the positive manners the students towards the lessons (Klawe, 1999; Rosas et. al., 2003; Prensky, 2003; Papastergiou, 2009).

\subsection{Purpose of Study}

The aim of this study is to adapt Digital Educational Games Usage Scale that was developed by Bonanno \& Kommers (2008) to Turkish language. For this purpose, firstly to ensure the validity of the scale linguistically, adaptation to Turkish language was conducted. After the Turkish language validity of the scale, item total correlation of the scale was examined. After the item analyses, structural validity of the scale were tested with CFA and EFA. After the validity effort was finalized, to carry out the reliability analyses of the scale, split-half and test-retest methods were used and data regarding to these analyses and operations were detailed below.

\subsection{Digital Educational Games Usage Scale (DEGUS)}

In these section sub-dimensions of the scale, definitions of the sub-dimensions and the meaning of the concept of game were included. Digital Educational Games Usage Scale consists of four sub-dimensions. These dimensions are; affective component, perceived usefulness, perceived control and behavioral component. The definition of 'game' is frequently stated in the scale, as well. The intent by the word 'game' is educational digital games. Digital educational games are designed by the help of technological tools to support learning of the student by involving emotional dimensions and social behaviors for determined targets. In these types of games, usually the determined acquirements are targeted for students to obtain. The attraction for student here is having fun in the process of learning and not getting bored of it. Briefly educational games aim to satisfy student while conducting teaching.

$>$ Affective Component [A]: Affective component represents the emotions of fear, hesitation and nervousness of the individual before the game and during the game.

$>$ Perceived Usefulness [U]: Perceived usefulness includes the behaviors of the individuals that stem from the beliefs of the individual about the advantages of educational games.

$>$ Perceived Control [C]: Perceived control defines the emotional and reactional behaviors of the individual while manipulating technological tools (using educational games). These abilities include self-learning the skills of the duty, having control abilities while using game tools and software and helping the others while carrying out the missions.

Behavioral Components [B]: Includes the positive behaviors to show willingness to play the educational games or the unwillingness to play the games.

\section{Method}

\subsection{Operation I: Method}

\subsubsection{Study Group}

DEGUS' adaptation to Turkish in terms of language validity is performed by 40 undergraduate students (59,3\% male, 40,7\% female) studying in the department of English Teaching in Education Faculty of Mustafa Kemal University in 2017-2018 academic year.

\subsubsection{Operation}

In order to gain the DEGUS measurement tool used by Bonanno \& Kommers (2008) for Turkish literature of the field, firstly the permissions of the researchers that developed this scale were granted via e-mails and the efforts of adapting to Turkish began.

Scale items were prepared from the beginning in forms and translated to Turkish by two academicians of Foreign Languages department. Afterwards, the scale items that were translated to Turkish by language experts were 
evaluated separately and finalized in a single form. The resulting Turkish form again was delivered to two different academicians in Foreign Languages department and scale items were translated back to English. It was found that re-translated form of DEGUS was similar and closely related to its English form. After that English and Turkish forms of the scale were delivered to faculty members of Assessment and Evaluation, Computer and Educational Information Technologies and Education Program and Teaching Departments in order to gain their opinion about the Turkish validity of the scale items. In the lights of the feedback and advices of the scholars, necessary changes were made and the final form of the scale was reached before the application.

\subsubsection{Findings}

As a result of the applications, a high level of correlation $(\mathrm{r}=.92 ; \mathrm{p}<.01)$ was found between the original form and translated form of the scale. This high level of correlation indicates a strong similarity between the actual scale and Turkish-adapted scale. Therefore, structural validity analyses were also performed on the scale.

\subsection{Operation II: Method}

\subsubsection{Study Group}

In the analyses to determine the structure of DEGUS in terms of factor, 150 students ( $\% 65,7$ female, $\% 34,3$ male) studying in Education Faculty of Mustafa Kemal University participated. While determining sample size or study group size in scale research, a special care was shown to have a sample size of at least 5 times the number of scale items (Erkuş, 2012). Thus, the scale research was performed with more than $21 * 5=105$ people that is 150 people.

\subsubsection{Operation}

Exploratory factor analysis (EFA) AND Confirmatory factor analysis (CFA) were conducted to reveal the structural validity of DEGUS. These analyses on DEGUS were performed on independent sample groups and exploratory factor analysis was initially applied on scale data. In the determination of scale items, the eigenvalues of the items were at least 1.00, factor load of the items were at least .30, items only take place at a single factor, items existing on two factors should have at least .10 factor load difference rules were considered (Büyüköztürk, 2017; Shevlin \& Lewis, 1999; Martin \& Newel, 2004; Schriesheim \& Eisenbach, 1995).

Data gathered from the exploratory factor analysis were tested together with item-factor structure for model suitability, also multiple fit indices were used. On fit indices $>.90$ for IFI, RFI, GFI, NFI, NFNFI and CFI; $<.08$ for RMSEA were utilized as criteria (Şimşek, 2007; Hu \& Bentler, 1999; Büyüköztürk, 2017). Besides, in terms of reliability of the scale, internal consistency operations, split-half reliability operations and test-retest operations were carried out. SPSS 15.0 and LISREL 8.80 software's were used for the reliability and validity analyses of the scale. In Table 1, Kaiser-Meyer-Olkin (KMO) and Bartlett test results regarding the factor analysis suitability of the data were shown.

Table 1. KMO and Barlett Sphericity Test Results

\begin{tabular}{lll}
\hline Kaiser-Meyer-Olkin Sampling Adequacy & Measurement & 0.782 \\
\hline \multirow{3}{*}{ Barlett's Sphericity Test Results } & Appr. Chi-square & 1223,400 \\
& Degree of Freedom & 253 \\
& Significance & 0.00 \\
\hline
\end{tabular}

To determine the suitability of the student data for exploratory factor analysis of DEGUS, KMO coefficient and Bartlett Sphericity Test were applied. The analyses showed that KMO coefficient was .90. Significance level of Bartlett Sphericity Test was calculated as .00. The fact that KMO value is more than .60 and is close to 1 shows the suitability of the data for the factor analysis and Bartlett sphericity Test's significance $(\mathrm{p}<.05)$ shows that correlations between the items ate meaningful (Bolat, 2017). In addition, the findings of the KMO and Bartlett Sphericity Tests implies that sample size is adequate and suitable for factor analyses.

\section{Findings}

\subsection{Related to Exploratory Factor Analysis (EFA)}

Eigenvalues pertaining to the final form of the factor structure and exploratory variances as a result of exploratory factor analysis were presented in Table- 2 . 
Table 2. Factor Eigenvalues and Exploratory Variances

\begin{tabular}{llll}
\hline Factor & \multicolumn{3}{l}{ Initial Eigenvalue } \\
\cline { 2 - 4 } & Total & Vari \% & Cumul \% \\
\hline 1 & 5,782 & 18,575 & 18,575 \\
2 & 3,198 & 10,274 & 28,849 \\
3 & 3,089 & 9,924 & 38,772 \\
4 & 1,918 & 6,162 & 45,934 \\
\hline
\end{tabular}

As seen in table 2, there are four factors with eigenvalues of more than 1.0. The variance explained by these four factors constitute \% 45, 934 of total variance. Comparing the eigenvalues and variances of the factors after the beginning and rotation, it was observed that eigenvalue of the first factor was decreasing while the eigenvalues of the other factors increase and distribute among each other homogeneously. The scree-plot graph, from which the breaking points of the scale are visible, is shown in Figure 1.

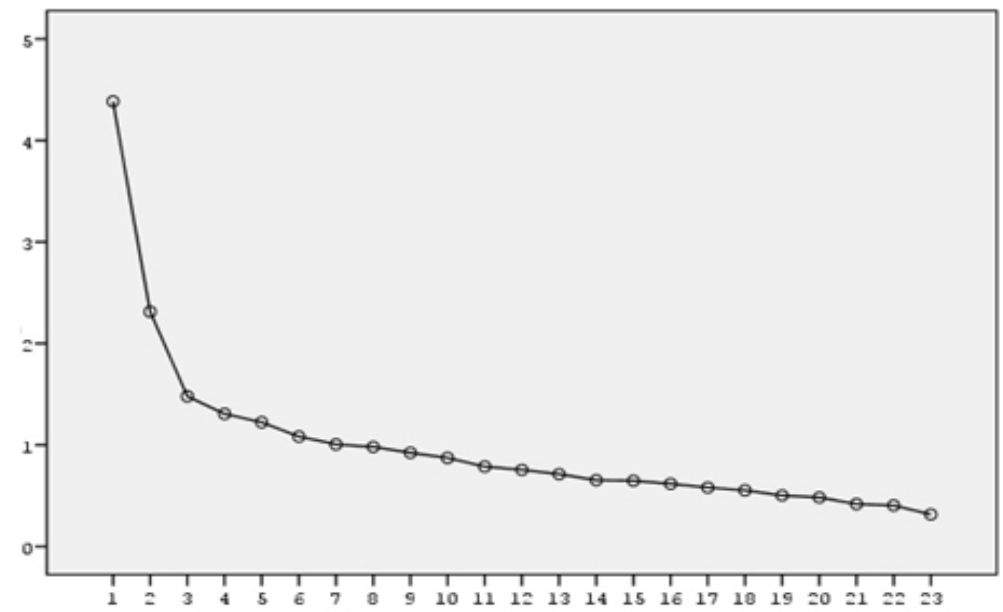

Figure 1. The Scree-plot Graph Related to Digital Educational Games Usage Scale

Investigating the figure-1, four different breaking points can be detected. The scree-plot graph states that the scale is composed of four factors. It is obvious that this figure is similar to the factor structure figure of the original scale. Factor load values and item total correlation values related to the four-factor structure of the scale are presented in Table-3.

Examining the Table 3, Digital Educational Games Usage Scale were applied to 137 teacher candidates and obtained results were subjected to factor analysis, without losing any item 21 items were distributed in a four-factor structure. For the reliability of DEGUS, examining each item's Cronbach Alpha reliability coefficients; internal consistency coefficient of "Affective Component(A)" sub-factor's items were 0.79, internal consistency coefficient of "Perceived Usefulness(U)" sub-factor's items were 0.77, internal consistency coefficient of "Perceived Control(C)" sub-factor's items was 0.79 and that of "Behavioral Components(B)" sub-factor's items was calculated as 0.80 . Reviewing the reliability coefficients of the sub-factors of the scale, it is clear that the scale had a high level of reliability. Tezbaşaran (1997) states that in a likert type scale the reliability coefficient should be as close to 1 as possible. Kalayc1 (2009) argues that Alpha coefficients of 0.60 or more are acceptable and valid. In this sense it can be observed that the values of the scale related to sub-dimensions are in adequate levels. This shows us the general structure and all the factors of the scale are reliable. 
Table 3. Factor Load Values, Item Total Correlation Values and Reliability Coefficients of Items

\begin{tabular}{|c|c|c|c|c|c|c|}
\hline \multirow[b]{2}{*}{ Item } & \multicolumn{4}{|c|}{ Factors } & \multirow[b]{2}{*}{$\begin{array}{l}\text { Item Total } \\
\text { Correlation }\end{array}$} & \multirow[b]{2}{*}{$\begin{array}{c}\text { Cronbach Alpha } \\
\text { Reliability }\end{array}$} \\
\hline & $\begin{array}{c}1 \\
\text { Affective } \\
\text { Component } \\
\text { (A) }\end{array}$ & $\begin{array}{c}2 \\
\text { Perceived } \\
\text { Usefulness } \\
\text { (U) }\end{array}$ & $\begin{array}{c}3 \\
\text { Perceived } \\
\text { Control } \\
\text { (C) }\end{array}$ & $\begin{array}{c}4 \\
\text { Behavioral } \\
\text { Components } \\
\text { (B) }\end{array}$ & & \\
\hline M1 & 0,60 & & & & ,602* & \\
\hline M5 & 0,51 & & & & ,534* & \\
\hline M8 & 0,59 & & & & ,619* & 0,79 \\
\hline M12 & 0,50 & & & & ,546* & \\
\hline M16 & 0,58 & & & &, $555^{*}$ & \\
\hline M20 & 0,61 & & & & ,655* & \\
\hline M2 & & 0,57 & & & ,591* & \\
\hline M6 & & 0,52 & & &, $572 *$ & \\
\hline M13 & & 0,71 & & & ,553* & 0,77 \\
\hline M17 & & 0,66 & & & ,647* & \\
\hline M21 & & 0,51 & & &, $509^{*}$ & \\
\hline M3 & & & 0,66 & &, $550 *$ & \\
\hline M7 & & & 0,59 & & ,531* & \\
\hline M9 & & & 0,53 & & ,524* & \\
\hline M11 & & & 0,59 & & ,556* & 0,79 \\
\hline M15 & & & 0,61 & & ,584* & \\
\hline M19 & & & 0,59 & & ,553* & \\
\hline M4 & & & & 0,68 & ,673* & \\
\hline M10 & & & & 0,56 &, $583^{*}$ & 0,80 \\
\hline M14 & & & & 0,62 & ,652* & \\
\hline M18 & & & & 0,61 & ,664* & \\
\hline
\end{tabular}

\subsection{Related to Confirmatory Factor Analysis (CFA)}

In order for DEGUS' original form to be validated with Turkish form, DFA was performed. Standard values after the DFA of DEGUS that is composed of factors and 21 items are given in Table 4.

Table 4. Adaptation Values of the Digital Educational Games Usage Scale

\begin{tabular}{ll}
\hline Fit Indice & Value \\
\hline Chi-sqr $\left(X^{2}\right)$ & 657.80 \\
P - value & 0.00 \\
Degree of freedom & 376 \\
Chi-sqr/sd & 2.7453 \\
RMSEA & 0.059 \\
SRMR & 0.052 \\
NFI & 0.94 \\
NNFI & 0.97 \\
CFI & 0.97 \\
IFI & 0.97 \\
GFI & 0.83 \\
AGFI & 0.80 \\
\hline
\end{tabular}


Many fit indices can be used to evaluate whether the model of the DFA is sufficient $\left(X^{2}=657.80 ; p<0.05\right.$; sd $=376$; $\mathrm{X}^{2} / \mathrm{sd}=2.7453 ; \mathrm{RMSEA}=0.059 ; \mathrm{SRMR}=0.052 ; \mathrm{NFI}=0.94 ; \mathrm{NNFI}=0.97 ; \mathrm{CFI}=0.97 ; \mathrm{IFI}=0.97 ; \mathrm{GFI}=0.83$; AGFI $=0.80$ ). Calculated factor loads of the scale items range between 0.47 and 0.79 . RMSEA value of less than .10 shows good fitting (Jöreskog \& Sörbom, 2001). Fitting values betwenn .90 and .95 are regarded as perfect inGFI, CFI, NFI, RFI, IFI ve AGFI indices (Bentler \& Bonett, 1980; Marsh, Hau, Artelt, Baumert \& Peschar, 2006). According to RMSEA, .08 is an acceptable value and .05 is the perfect value (Byrne \& Campbell, 1999; Brown and Cudeck, 1993). As a result of the exploratory factor analysis of Turkish version of DEGUS containing 4 factors and 21 items, it was concluded that scale model was statistically valid and suitable.

\subsection{The Study of Reliability}

In this research, the reliability of DEGUS was investigated by calculating test-retest reliability coefficient and internal consistency coefficient. Results related to reliability are shown in Table-5.

Table 5. t-Test Results of the Scale Re-test Application

\begin{tabular}{llll}
\hline Application & $\mathrm{N}$ & Re-test & Internal Cons. \\
\hline 1 & 30 & 0.78 & 0.88 \\
2 & 30 & & \\
\hline
\end{tabular}

The internal consistency of the scale was calculated to be .88 . To determine reliability of the scale by test-retest method, the scale was performed on 30 people with a separation of 2 weeks. Consequently test- retest reliability of the scale was calculated to be .78 after the applications.

\section{Conclusions}

In the research towards determining the reliability of Digital Educational Games Usage Scale (DEGUS), internal consistency, half split tests and test-retest methods were utilized. In the analyses of the scale, Cronbach Alpha which is the total internal consistency coefficient of the scale was found as .82 , test-retest reliability was calculated as .88 . Considering that the reliability levels to be used in researches and predicted for measurement tools is .70 (Tezbaşaran, 1996), Sperman-Brown reliability coefficient that determines the coherence between internal consistency of the scale and obtained test points shows that measurement tool is reliable.

After the item analyses it was found that total item correlations ranged between .50 and .66 . The items with total item correlation of .30 and more are accepted to distinguish the measured characteristics sufficiently (Büyüköztürk, 2017). Therefore, it can be stated that scale item's total item correlations are in adequate levels.

Validity and reliability analysis results of DEGUS reveal that DEGUS is a valid and reliable measurement tool reaching the required levels. The Turkish version of the scale might be used for measuring high level thinking skills. The scale developed by Bonanno \& Kommers (2008) and adapted to Turkish is a reliable and valid scale with all four of its dimensions.

The survey of the study only uses university students as the sample group. However, it is thought that DEGUS is an appropriate scale to gather the opinions of students on educational digital games. With the help of this scale, the reason why students do not prefer to use digital games can be enlightened. The scale can be utilized for the purpose of obtaining the reviews of the students on digital games. Thereby, a way for designing more effective and useful digital games can be opened.

\section{Suggestions}

Digital games alter the cognitive and affective development of students through some variables. In literature it is seen that male students are more successful and confident on the use of digital games compared to female students (Klimmt \& Hartmann 2006; Habgood \& Ainsworth, 2011). Consequently, male students become more accomplished in activities involving digital games with respect to the female students. Therefore, there should be the necessary studies to get female students to higher levels in this sense.

One of the most crucial variables of the digital games is the designation of the game. The digital games should be designed such that individuals of all kinds and levels of ability may play (King-Sears, 2009). 
Digital games should be intuitional and provide easy-use to the students. Some students cannot play every game by using the combination of different letters on keyboard. Therefore, the games should be designed such that every student can easily play from the keyboard (Hall et. al. 2012).

In digital games, in-game feedbacks must be comprehendible, stating clearly what the user should do (Mace, 2007). For this reason, in-game feedbacks, information and content should be appropriate for students with different perception levels (King-Sears, 2009).

In order for digital games to be used in education successfully, teachers should also have a positive attitude towards educational digital games and have enough self-confidence towards the use of digital games (Foster \& Shah, 2016).

\section{References}

Admiraal, W., Huizenga, J., Akkerman, S., \& Dam, G. T. (2011). The concept of flow in collaborative game-based learning. Computers in Human Behavior, 27(3), 1185-1194. https://doi.org/10.1016/j.chb.2010.12.013

Bartek, K., \& Nocar, D. (2016). Mathematic education support by digital learning objects. EDULEARN, 16, 3249-3253. https://doi.org/10.21125/edulearn.2016.1707

Bolat, Y. (2017). Eğitim programı okuryazarlı̆̆ kavramı ve eğitim programı okuryazarlığı ölçeği. Turkish Studies International Periodical for the Languages, Literature and History of Turkish or Turkic, 12(18), 121-138. https://doi.org/10.7827/TurkishStudies.12103

Bonanno, P., \& Kommers, P. A. M. (2008). Exploring the in fluence of gender and gaming competence on attitudes towards using in structional games. British Journal of Educational Technology, 39(1), 97-109.

Boulos, M. N. K., Hetherington, L., \& Wheeler, S. (2007). Second Life: An over view of the potential of 3 - D virtual worlds in medical and health education. Health Information \& Libraries Journal, 24(4), 233-245. https://doi.org/10.1111/j.1471-1842.2007.00733.x

Brumbaugh, D. K., \& Rock, D. (2010). Teaching secondary mathematics. Routledge: New York.

Büyüköztürk, Ş. (2017). Sosyal bilimler için veri analizi el kitabı. Ankara: Pegem Akademik Yayıncılık. https://doi.org/10.14527/9789756802748

Chen, H. R., Liao, K. C., \& Chang, J. J. (2015). Design of digital game-based learning system for elementary mathematics problem solving. 8th International Conference on Ubi-Media Computing (UMEDIA), 24-26 August, 303-307, IEEE. https://doi.org/10.1109/UMEDIA.2015.7297475

Chen, Z. H., Liao, C. C., Cheng, H. N., Yeh, C. Y., \& Chan, T. W. (2012). Influence of game quests on pupils' enjoyment and goal-pursuing in math learning. Educational Technology \& Society, 15(2), 317-327.

Clark, D., Nelson, B., Sengupta, P., \& D’Angelo, C. (2009). Rethinking science learning through digital games and simulations: Genres, examples, and evidence. In Learning science: Computer games, simulations, and education work shop sponsored by the National Academy of Sciences, Washington, DC.

Dönger, A., Özkartal, Z., \& Sarıöz, O. (2017). An Examination of Anxiety Levels of the Students Towards Scientific Research. International Refereed Journal of Humanities and Academic Science, 21, 22-36. https://doi.org/10.17368/UHBAB.2017.3.1.1

Ennis, R. H. (1989). Critical Thinking and subject specificity: Clarification and needed research. Educational Researcher, 43(2), 44-48. https://doi.org/10.3102/0013189X018003004

Erkuş, A. (2012). Psikolojide ölçme ve ölçek geliştirme-1: Temel kavramlar ve işlemler. Ankara: Pegem Akademi.

Feng, C. (2008). Playing with shadows: Exposing the black market for online game password the ft. Virus Bulletin Conference, 1-3 October, 207-214.

Foster, A., \& Shah, M. (2016). Knew me and new me: Facilitating student identity exploration and learning through game integration. International Journal of Gaming and Computer-Mediated Simulations, 8(3), 39-58. https://doi.org/10.4018/IJGCMS.2016070103

Gelen, İ., \& Özer, B. (2009). Oyunlaştırmanın beşinci sınıf matematik dersinde problem çözme becerisi ve derse karş1 tutum üzerindeki etkisi. E-Journal of New World Sciences Academy, 5(1), M. No: 1 CO115.

Habgood, M. J., \& Ainsworth, S. E. (2011). Motivating children to learn effectively: Exploring the value of intrinsic integration in educational games. The Journal of the Learning Sciences, 20(2), 169-206. 
https://doi.org/10.1080/10508406.2010.508029

Hall, T. E., Meyer, A., \& Rose, D. H. (Eds.). (2012). Universal design for learning in the classroom: Practical applications. Guilford Press: New York.

Hu, L. T., \& Bentler, P. M. (1999). Cutoff criteria for fit indexes in covariance structural analysis: Conventional criteria versus new alternatives. Structural Equation Modeling, 6(1), 55-65. https://doi.org/10.1080/10705519909540118

Jong, J. T., Hong, J. C., \& Yen, C. Y. (2013). Persistence temperament associated with children playing math games between touch panel and embodied interaction. Journal of Computer Assisted Learning, 29(6), 569-578. https://doi.org/10.1111/jcal.12017

Kim, S., \& Chang, M. (2010). Computer games for the math achievement of diverse students. Educational Technology \& Society, 13(3), 224-232.

King-Sears, M. (2009). Universal design for learning: Technology and pedagogy. Learning Disability Quarterly, 32(4), 199-201. https://doi.org/10.2307/27740372

Klawe, M. (1999). Computer games, education and interfaces: The E-GEMS project. Proceedings of the graphics interface conference, 2-4 June, 36-39.

Klimmt, C., \& Hartmann, T. (2006). Gender and computer games: exploring females' dislikes. Journal of Computer Mediated Communication, 11(4), 910-931. https://doi.org/10.1111/j.1083-6101.2006.00301.x

Li, T. M., Chau, M., Sung, W. K., Lee, A. J., Wong, P. W., \& Yip, P. S. (2016). Design and evaluation of a Facebook game for self-directed e-learning. Knowledge Management \& E-Learning: An International Journal (KM\&EL), 8(3), 464-480.

Martin, C. R., \& Newell, R. J. (2004). Factor structure of the hospital anxiety and depression scale in individuals with facial disfigurement. Psychology Health and Medicine, 3, 327-336. https://doi.org/10.1080/13548500410001721891

Mayo, M. J. (2007). Games for science and engineering education. Communications of the ACM, 50(7), 30-35. https://doi.org/10.1145/1272516.1272536

Papastergiou, M. (2009). Exploring the potential of computer and video games for health and physical education: A literature review. Computers \& Education, 53(3), 603-622. https://doi.org/10.1016/j.compedu.2009.04.001

Prensky, M. (2003). Digital game-based learning. Computers in Entertainment (CIE), 1(1), $21-21$. https://doi.org/10.1145/950566.950596

Rosas, R., Nussbaum, M., Cumsille, P., Marianov, V., Correa, M., \& Flores, P. (2003). Beyond Nintendo: Design and assessment of educational video games for first and second grade students. Computers and Education, 40(1), 71-94. https://doi.org/10.1016/S0360-1315(02)00099-4

Sarıgöz, O. (2012). Assessment of the high school student' critical thinking skills. Procedia Social and Behavirol Sciences, 46, 5315-5319. https://doi.org/10.1016/j.sbspro.2012.06.430

Sarıgöz, O. (2016). Anthropological attitudes and views of the teachers towards lifelong learning. The Anthropologist, 24(2), 598-610. https://doi.org/10.1080/09720073.2016.11892054

Schriesheim, C. A., \& Eisenbach, R. J. (1995). An exploratory and confirmatory factor analytic investigation of item word in geffects of obtained factor structures of survey question naira measures. Journal of Management, 6, 1177-1193. https://doi.org/10.1177/014920639502100609

Shevlin, M.E., \& Lewis, C.A. (1999). There vised social anxiety scale: Exploratory and confirmatory factor analysis. The Journal of Social Psychology, 2, 250-252. https://doi.org/10.1080/00224549909598381

Şimşek, Ö. F. (2007). Yapısal eşitlik modellemesine giriş: Temel İlkeler ve LISREL Uygulamaları. Ankara: Ekinoks Yayıncilik.

Tezbaşaran, A. A. (1996). Likert tipi ölçek geliştirme kılavuzu. Ankara: Türk Psikologlar Derneği Yayınları.

Van Garderen, D. (2007). Teaching students with LD to use diagrams to solve mathematical word problems. Journal of Learning Disabilities, 40(6), 540-553. https://doi.org/10.1177/00222194070400060501

Virk, S., Clark, D., \& Sengupta, P. (2015). Digital games as multi representational environments for science learning: Implications for theory, research, and design. Educational Psychologist, 50(4), 284-312. 
https://doi.org/10.1080/00461520.2015.1128331

Yang, Y. T. C., \& Chang, C. H. (2013). Empowering students through digital game author ship: Enhancing concentration, critical thinking, and academic achievement. Computers \& Education, 68, 334-344. https://doi.org/10.1016/j.compedu.2013.05.023

Appendix I. Digital Educational Games Usage Scale Items (Turkish)

\begin{tabular}{|c|c|c|c|c|c|c|}
\hline z & MADDELER & 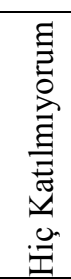 & 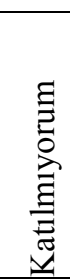 & $\begin{array}{l}\Xi \\
\Xi \\
\text { त्ञ } \\
\mathbb{Z} \\
\mathbb{Z}\end{array}$ & 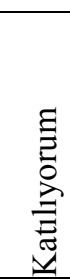 & 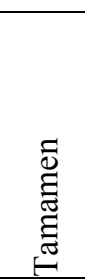 \\
\hline 1 & $\begin{array}{l}\text { Popüler bir dijital oyunu oynama firsatı verildiğinde oyun içerisinde } \\
\text { gezinirken sorun yaşayacağımdan korkarım. }\end{array}$ & $(0)$ & (1) & (2) & (3) & (4) \\
\hline 2 & Eğitsel dijital oyunlar beni rahatlattı̆̆ için daha iyi çalışıyorum. & $(0)$ & (1) & (2) & (3) & (4) \\
\hline 3 & $\begin{array}{l}\text { Dijital bir oyun hakkında bilmem gereken birçok bilgiyi kendi kendime } \\
\text { öğrenebilirim }\end{array}$ & (0) & $(1)$ & (2) & (3) & (4) \\
\hline 4 & Eğer bir konu dijital oyunla öğretilirse öğrenmekte zorlanırım. & (0) & (1) & (2) & (3) & (4) \\
\hline 5 & $\begin{array}{l}\text { Aptal gibi görünebilirim endişesiyle eğitsel dijital bir oyunu kullanmakta } \\
\text { tereddüt ederim. }\end{array}$ & $(0)$ & $(1)$ & $(2)$ & (3) & (4) \\
\hline 6 & $\begin{array}{l}\text { Eğitsel dijital oyunlar fazladan çaba gerektiren bir dereceye kadar öğrenme } \\
\text { deneyimlerimizi zenginleştirir. }\end{array}$ & (0) & (1) & (2) & (3) & (4) \\
\hline 7 & $\begin{array}{l}\text { Bilgisayarda oyun oynadığım zaman oyunu tamamen kontrol etmekte } \\
\text { zorluk yaşıyorum. }\end{array}$ & $(0)$ & $(1)$ & (2) & (3) & (4) \\
\hline 8 & Eğitsel dijital bir oyunu kullandığımda tedirgin olmuyorum. & $(0)$ & (1) & (2) & (3) & (4) \\
\hline 9 & $\begin{array}{l}\text { Eğitsel dijital bir oyun oynarken ne yapmak istiyorsam bilgisayarda } \\
\text { yapabilirim. }\end{array}$ & $(0)$ & (1) & (2) & (3) & (4) \\
\hline 10 & Eğitsel dijital oyunları sadece söylendiğinde oynarım. & $(0)$ & $(1)$ & (2) & (3) & (4) \\
\hline 11 & $\begin{array}{l}\text { Eğitsel dijital bir oyunu kullanırken yanımda deneyimli bir kişiye ihtiyaç } \\
\text { duyarım. }\end{array}$ & $(0)$ & $(1)$ & (2) & (3) & (4) \\
\hline 12 & Eğitsel dijital oyunları oynamak beni hiçbir şekilde korkutmuyor. & $(0)$ & $(1)$ & (2) & (3) & (4) \\
\hline 13 & $\begin{array}{l}\text { Eğitsel dijital bir oyundan elde edeceğimiz veya ulaşacağımız birçok } \\
\text { kazanımı başka yollarla da elde edebiliriz. }\end{array}$ & $(0)$ & $(1)$ & (2) & (3) & (4) \\
\hline 14 & Eğitsel dijital oyunları oynamaktan kaçınırım. & $(0)$ & $(1)$ & (2) & (3) & (4) \\
\hline 15 & $\begin{array}{l}\text { Eğitsel dijital bir oyunu kullanırken bir problemle karşılaştı̆̆ımda } \\
\text { genellikle o problemi bir ya da birden fazla yolla çözebilirim. }\end{array}$ & (0) & $(1)$ & (2) & (3) & (4) \\
\hline 16 & $\begin{array}{l}\text { Düzeltemeyeceğim hatalar yapmaktan korktuğumdan dolayı bilgisayarı } \\
\text { oyun oynamak için kullanmakta tereddüt ederim. }\end{array}$ & (0) & $(1)$ & $(2)$ & (3) & (4) \\
\hline 17 & Eğitsel dijital oyunlar, öğrenmek için daha ilginç ve yaratıcı yollar sunar. & $(0)$ & $(1)$ & (2) & (3) & (4) \\
\hline 18 & Okul boyunca düzenli olarak eğitsel dijital oyunları kullanacağım. & $(0)$ & $(1)$ & (2) & (3) & (4) \\
\hline 19 & $\begin{array}{l}\text { Eğitsel dijital bir oyunu kullanmanın en iyi yollarını bana anlatacak birine } \\
\text { ihtiyaç duyarım. }\end{array}$ & $(0)$ & (1) & (2) & (3) & (4) \\
\hline 20 & Eğitsel dijital oyunlar beni rahatsız eder. & $(0)$ & $(1)$ & (2) & (3) & (4) \\
\hline 21 & Eğitsel dijital oyunlar daha verimli öğrenmeler için olanaklar sağlar. & $(0)$ & $(1)$ & (2) & (3) & (4) \\
\hline
\end{tabular}

